\title{
Research on Structure of Steel-concrete Joint Section in Hybrid Girder of a Grand Bridge
}

\author{
Weiwei Chen ${ }^{1, a}$, Bin Liang ${ }^{1, b}$ and Wenjing Wang ${ }^{1, c}$ \\ Civil Engineering School, Henan University of Science and Technology, Luoyang 471023, China \\ a1278216732@qq.com, bliangbin4231@163.com, ${ }^{\mathrm{a}} 742094540 @ q q . c o m$
}

Keywords: hybrid girder; steel-concrete joint section; structure characteristics; PBL connector; Abstract. Structure of steel-concrete joint section in hybrid girder of a grand bridge is studied. Taking Weihe grand bridge as an engineering example, structure combination of steel-concrete joint section and detail structure design including joint section connector, longitudinal prestressed reinforcement, steel lattice are analyzed. Combined the calculation and analysis, the connection form of steel-concrete joint section of Weihe grand bridge is determined. The results show that the joint section stiffness changes relatively uniform and stress transition is smooth. The structure design of steel-concrete joint section of this bridge is reasonable.

\section{Introduction}

Steel-concrete joint section is a transition section of the two materials of steel and concrete which is a key part of ensuring steel beam and concrete beam smooth transmission force, bearing together. To a certain extent, it determines the success or failure of the entire bridge. The mechanical performance and the using performance are not only influenced by material properties, but also closely related to the structure of steel-concrete joint section [1,2].

The Tatara bridge in Japan, Nanchang Hero bridge have different structure composition, but the overall form is consistent. The main components of joint section and internal force, deformation transfer mechanism are basically the same and the stiffness transition section structure form is also basically the same[3]. Generalized steel-concrete joint section can be divided into three basic components, namely the transition section of concrete beam, steel-concrete section and steel girder transition section.

At present, domestic on the design and construction of steel-concrete composite section has not yet been studied systematically. Norms and standards have no guiding to follow. There are many problems to be solved[4]. Therefore, taking Weihe grand bridge as an engineering example, structure combination of steel-concrete joint section and detail structure design including joint section connector, longitudinal prestressed reinforcement, steel lattice are analyzed. It promotes the development of steel-concrete joint section technology and it also has a positive practical significance.

\section{Project Profile}

Weihe bridge is a super-large bridge in Shanxi Xitong highway across Wei River, the total length of $1049.25 \mathrm{~m}$. The ratio of the side span and middle span at the last span in the first joint variable cross-section reaches 1:1. If reinforced concrete box girder is used, the structure will be difficult to meet the specification requirements. So the $53.68 \mathrm{~m}$ steel box girder has been set in the last span to reduce weight. And the joint section has been set between the two box girders that constructed the steel-concrete continuous box beam. 
90m side span of the first joint of the main bridge steel-concrete joint section in hybrid girder, includes $36 \mathrm{~m}$ prestressed concrete box girder and $53.68 \mathrm{~m}$ steel box girder. Between concrete box girder and steel box girder, $2.5 \mathrm{~m}$ steel-concrete joint section is set. The section of steel box girder is single box four chambers, height of $3.5 \mathrm{~m}$. C55 concrete and Q345D steel plate are mainly adopted.

\section{Overall Structure of Steel-Concrete Joint Section}

Steel-concrete joint section. Concrete box girder and steel box girder are connected by joint section. In the steel-concrete joint section top, bottom and inside of the web set perforated plate connector (PBL connector). The length is $2.5 \mathrm{~m}$ and the thickness of the steel plate is $20 \mathrm{~mm}$. It opens $8 \Phi 80 \mathrm{~mm}$ or $\Phi 70 \mathrm{~mm}$ round holes. Vertical and horizontal general steel or prestressed tendons through the round hole in order to enhance the effect of connection.

$50 \mathrm{~mm}$ thickness subplate (bearing plate) is set at joint surface of steel box girder and concrete box girder. Inner side welds perforated plate connector and outer side welds steel box girder stiffness transition section steel members. External use continuous interlinked top, bottom and web. The thickness are respectively $26 \mathrm{~mm}, 24 \mathrm{~mm}$ and $28 \mathrm{~mm}$. Longitudinal prestressed steel beam use low relaxation prestressed steel strand, which anchors in the $50 \mathrm{~mm}$ plate outer. Structure of steel-concrete joint section is shown in Fig.1.

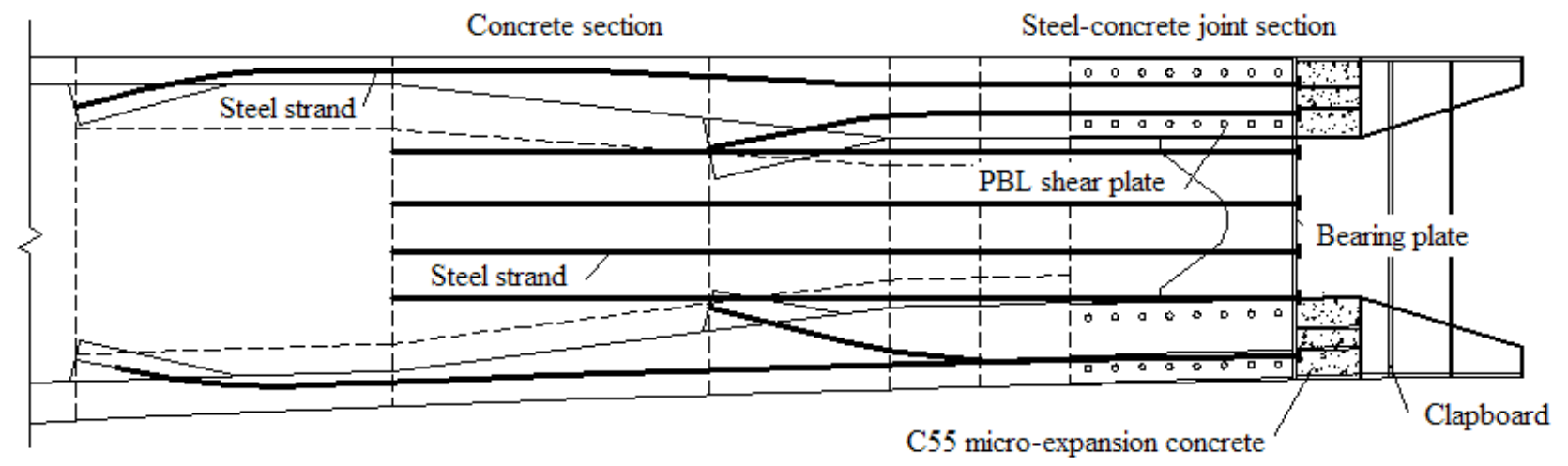

Fig.1 Structure of steel-concrete joint section(unit,mm)

Concrete box girder. The section of prestressed concrete box girder is single-box with double room. The appearance of structure is consistent with steel box girder structure. The bridge deck width is $41 \mathrm{~m}$ and the height of beam is $32 \mathrm{~cm}$. Section roof thickness is $18 \mathrm{~cm}$. Thick plate is $42.5 \mathrm{~cm}$ and inner web thickness is $60 \mathrm{~cm}$. Concrete box girder cross-section is shown in Fig. 2 .

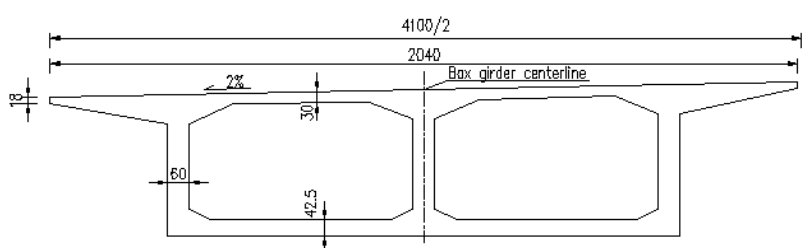

Fig.2 Concrete box girder cross-section (unit, cm)

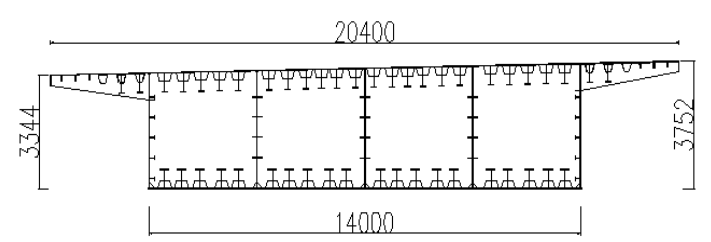

Fig.3 Structure of steel-concrete joint section(unit, mm)

Steel box girder. After the steel-concrete joint section, $0.7 \mathrm{~m}$ long anchor sealing area is set in order to realize the smooth transition of the stiffness of the structure. After sealing anchor zone, the variable high stiffening rib is set. The front of $U+T$ shaped welds in the end plate of sealing anchor zone. Total length of steel box girder stiffness transition section is $2.5 \mathrm{~m}$. Steel box girder section is shown in Fig.3. 


\section{Detail Structure of Steel-concrete Joint Section}

Connector structure characteristics. Belonging to the flexible connection, welding stud is the most commonly used shear connector. It bears the shearing force between steel and concrete and it can resist the wave effect between the two at the same time. As the supporting compressive stress on concrete is non-uniform distribution and omnidirectional, welding stud is adapt to more complex situation of the stress distribution. Fig. 4 shows the welding stud under construction.

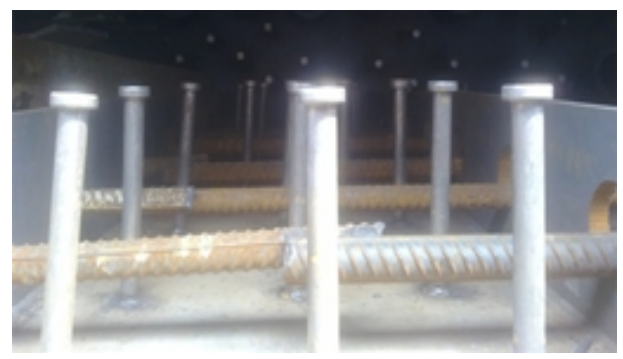

Fig.4 Welding stud under construction

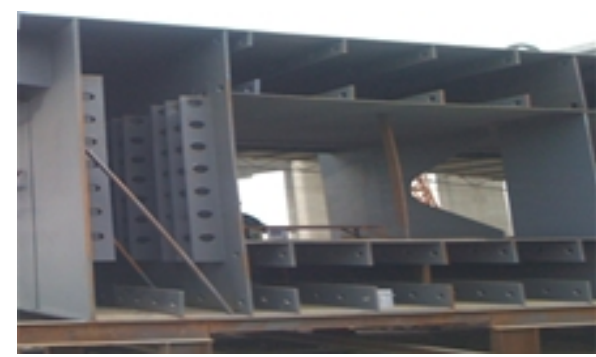

Fig.5 PBL connector under construction

PBL connector is a steel plate connector with circular holes belonging to the rigid connection. It bears the force between steel and concrete relying on concrete column in the steel plant round hole. It has three advantages including large shear stiffness, good anti-fatigue performance and constructing convenience. Fig.5 is the PBL concrete under construction.

Longitudinal prestress connection structure characteristics. In connecting structure of steel-concrete joint section, bearing plate of steel beam and concrete box beam are connected together by the vertical prestressed steel beam. Longitudinal prestress increases the friction between the bearing plate and concrete so as to increases the shear bearing capacity. At the same time, it makes the concrete of steel-concrete joint section in the confined state of low level so as to improves the ability of joint surface bearing longitudinal tensile. Thus the function of joint surface bearing and transferring loads is realized.

Prestressed tendon in steel-concrete composite continuous beam of Weihe grand bridge use $1 \times 7$ structure of steel strand which belongs to the high strength and low relaxation steel strand. The nominal diameter of single beam is $\Phi^{s} 15.2 \mathrm{~mm}^{2}$ and nominal cross section area is $140 \mathrm{~mm}^{2}$. Standard strength $\left(f_{p k}\right)$ is $1860 \mathrm{~N} / \mathrm{mm}^{2}$ and design of longitudinal tensioned control stress $\left(0.72 f_{p k}\right)$ is $1339.2 \mathrm{~N} / \mathrm{mm}^{2}$. Longitudinal prestressed reinforcement figure is shown in Fig. 1 and Tab.1 is the main mechanical parameters of prestressed tendon.

\begin{tabular}{|c|c|c|c|}
\hline $\begin{array}{c}\text { Steel } \\
\text { bundle } \\
\text { specificati } \\
\text { on }\end{array}$ & $\begin{array}{l}\text { Tension control stress } \\
\qquad / \sigma_{\text {con }} \\
\qquad N / \mathrm{mm}^{2}\end{array}$ & $\begin{array}{c}\text { Tensile strength } \\
\qquad / f_{p} \\
N / \mathrm{mm}^{2}\end{array}$ & $\begin{array}{l}\text { Modulus of elasticity } \\
/ E_{p} \quad N / \mathrm{mm}^{2}\end{array}$ \\
\hline $12 \Phi^{s} 15.2$ & 1339.2 & 1260 & $1.95 \times 10^{5}$ \\
\hline
\end{tabular}

Tab.1 Main mechanical parameters of prestressed tendon

Steel lattice structure characteristics. At the end of steel-concrete joint section set the $0.7 \mathrm{~m}$ long seal anchor zone with $26 \mathrm{~mm}$ thick stiffening rib inside and $26 \mathrm{~mm}$ thick end plate in the end. Composed of inserted plate, top, bottom and stiffening rib, the steel compartment is poured C55 micro expansion concrete in the internal after the prestressed construction. Then it forms the joint section with steel compartment. Tab.2 is the mechanical parameters of concrete.

Taking steel-concrete joint section as the research object, the model is established in ANSYS finite element software. The full length of the model is $21 \mathrm{~m}$ including $11 \mathrm{~m}$ transition section of concrete box beam, $2.5 \mathrm{~m}$ of steel-concrete joint section, $2.5 \mathrm{~m}$ stiffness transition section of steel 
box beam and $5 \mathrm{~m}$ steel box beam. Steel and concrete composite stiffness calculation results are listed in tab.3.

\begin{tabular}{|c|c|c|c|}
\hline $\begin{array}{c}\text { Concrete strength } \\
\text { grade }\end{array}$ & $\begin{array}{c}\text { Modulus of elasticity / } E \\
\mathrm{MPa}\end{array}$ & $\begin{array}{c}\text { Density / } \rho \\
\mathrm{kg} / \mathrm{m}^{3}\end{array}$ & $\begin{array}{c}\text { Poisson ratio } \\
\mathrm{/N}\end{array}$ \\
\hline $\mathrm{C} 55$ & 35500 & 2500 & 0.2 \\
\hline $\mathrm{C} 40$ & 32500 & 2500 & 0.2 \\
\hline
\end{tabular}

Tab.2 Mechanical parameters of concrete

\begin{tabular}{|c|c|c|c|c|c|}
\hline Section position & $\begin{array}{c}\text { Area }( \\
\left.m^{2}\right)\end{array}$ & $\begin{array}{c}I_{x x}\left(m^{4}\right. \\
)\end{array}$ & $\begin{array}{c}I_{y y}\left(m^{4}\right. \\
)\end{array}$ & $\begin{array}{c}I_{z z}\left(m^{4}\right. \\
)\end{array}$ & $\begin{array}{c}\text { Bending } \\
\text { stiffness } \\
E \cdot I_{y y}\left(N \cdot m^{2}\right. \\
\text { ) }\end{array}$ \\
\hline Concrete section & 33.57 & 159.00 & 56.30 & 774.00 & $1.999 \times 10^{12}$ \\
\hline $\begin{array}{l}\text { Steel - Concrete joint } \\
\text { section(concrete part) }\end{array}$ & 33.57 & 159.00 & 56.30 & 774.00 & \multirow[b]{2}{*}{$2.932 \times 10^{12}$} \\
\hline $\begin{array}{l}\text { Steel - Concrete joint } \\
\text { section(steel box girder } \\
\text { part) }\end{array}$ & 2.41 & 8.49 & 4.53 & 59.70 & \\
\hline $\begin{array}{c}\text { Steel box } \\
\text { girder stiffness transition } \\
\text { section } \\
\text { U+T middle position }\end{array}$ & 2.64 & 7.95 & 5.37 & 70.20 & $1.106 \times 10^{12}$ \\
\hline $\begin{array}{l}\text { Steel box girder } \\
\text { stiffness transition } \\
\text { section }\end{array}$ & 1.76 & 7.38 & 3.66 & 50.80 & $7.540 \times 10^{11}$ \\
\hline $\begin{array}{l}\text { Standard steel box } \\
\text { girder section }\end{array}$ & 1.27 & 4.85 & 2.60 & 37.40 & $5.356 \times 10^{11}$ \\
\hline
\end{tabular}

\section{Tab.3 Steel - concrete composite stiffness calculation results}

By calculation and analysis, the results show that stiffness changes relatively uniform and stress transition is smooth. The construction design of steel-concrete joint section is reasonable.

\section{Conclusions}

The overall structure and the detail structure of steel-concrete joint section are analyzed. The detail structure includes connector, longitudinal prestressed reinforcement and steel lattice. At present, the Weihe grand bridge has been built and opened to traffic. The good operating condition verifies that the structural design of steel-concrete joint section is reasonable. And it also provides the reference basis for the design of similar steel-concrete joint section.

\section{References}

[1] C.H. Zou, Analysis on structure of steel-concrete joint section in hybrid girder rigid frame bridge, D. Southwest Jiaotong University.(2013) (in Chinese)

[2] J.Y. Cai, Design for steel-concrete joint segment of cable-stayed bridge with hybrid girder, J. Railway Standard Design. 1(2014) 68-71. 
[3] P.F. Gao, Local stress analysis and structural form research for joint part of hybrid girder of Xiaolan bridge, D. Beijing Jiaotong University. (2012) (in Chinese)

[4] W.B. He, Y.Q. Liu, R.R. Wang, Analysis of joint section structure of hybrid girder of Jiujiang Changjiang river highway bridge, J. Bridge Construction. 1(2012)30-35. (in Chinese) 